\title{
RPL13 wt Allele
}

National Cancer Institute

\section{Source}

National Cancer Institute. RPL13 wt Allele. NCI Thesaurus. Code C53154.

Human RPL13 wild-type allele is located in the vicinity of 16q24.3 and is approximately 4 $\mathrm{kb}$ in length. This allele, which encodes $60 \mathrm{~S}$ ribosomal protein L13, is involved in the modulation of messenger RNA translation. Aberrant expression of the gene is linked to benign breast cancer. 